http://dx.doi.org/10.4314/jae.v18i2.20

\title{
Determinants of Adoption of Improved Maize Varieties among Resource-Poor Households in Kano and Katsina States, Nigeria
}

\section{Umar, S. *, Musa, M.W. and Kamsang, L.}

Department of Agricultural Economics and Rural Sociology, Faculty of Agriculture/Institute for Agricultural Research, Ahmadu Bello University, PMB 1044, Zaria-Nigeria

*Corresponding email: sulaimanumar@hotmail.com Mobile Phone No.: +234 8068488698

\section{Abstract}

The study examined the factors influencing the adoption of improved maize varieties introduced under the Katsina-Kano-Maradi Pilot Learning Site (KKMPLS) of the IITA Sudan Savannah Taskforce. Using stratified sampling technique 160 farmers spread across five farming communities within Katsina and Kano States Nigeria were randomly selected. Data obtained were analyzed using probit regression model. Eleven variables were hypothesized to influence the probability of farmers' adoption of improved maize varieties out of which four were found to be significantly influencing adoption of improved maize varieties in the study area. Household size and marital status of the farmers were found to be significant at 5\% each; however, the former was negative while the later was positively related to adoption. Adoption of improved maize varieties was positively influenced by both participation in promotional activities and educational level of household head at $1 \%$ and $10 \%$ levels of significance respectively. It is, therefore, recommended that participatory approach should be encouraged in disseminating improved agricultural technologies like this because, participation is the most important factor influencing adoption of improved maize technologies in the study area.

Keywords: adoption, household, improved maize, participation.

\section{Introduction}

Apart from having a considerable potential to enhance food security and the productivity and sustainability of the crop-livestock system, maize has been found to increase annual income of farm households in Nigeria by $25 \%$ (Dugje et al ., 2009). Hence, it is currently cultivated all over the country, replacing hitherto more important cereals such as sorghum and millet in the fields. Because of such potentials of maize, production is rapidly spreading into the drier Savannah zones of West Africa.

Scientists in the International Institute of Tropical Agriculture in collaboration with Institute for Agricultural Research, Ahmadu Bello University, Samaru-Zaria, have developed agricultural technologies that enhance efficiency and address the several constraints facing maize production in northern Nigeria. These involves breeding and promoting suitable maize varieties which are higher yielding; more resistant to adverse ecological conditions such as drought, pests and diseases; and more efficient in the uptake and use of soil applied N (Kamara et al., 2003) than local varieties. Some of these improved varieties together with their attributes are shown in Table 1 below.

Table 1: Some of the varieties developed and disseminated by IITA in Savannah 
belts of Nigeria

\begin{tabular}{ll}
\hline Variety & Characteristics \\
\hline 99EVDTSTR & $\begin{array}{l}\text { Tolerant to Striga hermonthica weed and drought, and matures in 80-90 } \\
\text { days. It was released as SAMMAZ 27 }\end{array}$ \\
2009EVDTSTR & Sister line of 99EVDT. \\
99TZEEY STR & Striga resistant, extra early and yellow maize. It matures in 75-80 days \\
2000 SYN EE & Striga resistant, extra early and white, matures in 75-80 days. \\
2004 TZEE W & White, extra early and matures in 75-80 days. \\
\hline
\end{tabular}

\section{Purpose of the Study}

Thereafter, the challenge was the dissemination of these varieties among farmers in the Sudan Savannas area of Nigeria. Although several of these varieties have been released in Nigeria, they have not been widely distributed and adopted among farmers in northern Nigeria. A baseline study by Ayanwale et al . (2011) showed that only $38 \%$ of farmers in communities in Kano were aware of improved maize varieties and only the $38 \%$ adopted improved varieties. A study, such as this, that provides information on whether the farmers are growing these varieties and the reasons that promote or prevent adoption is very important. It would provide feedback to the scientists on the suitability of the maize varieties and farmer-preferred traits that could be considered during varietal development. It also provides information on socio-economic factors that should be addressed by policy makers to enhance rapid adoption of the improved technologies. The main objective of this study was to assess the factors determining the adoption of improved maize varieties in the study area.

\section{Methodology}

This study was conducted in Kumurya, Satigal and Gabo communities of Kano State; and Doga and Takatsaba communities of Katsina State, both in northern Nigeria. There was no complete list of farmers in these communities but a list of maize farmers was generated with the help the community leaders and extension agents. A stratified sampling technique was used where the population was first partitioned into participants (those who participated and received interventions and via the activities conducted by IITA) and non participants. From each community, 20 participants and 20 non-participants were randomly selected giving a total of 200 respondents who were interviewed using a well structured and pre-tested questionnaire. Descriptive statistics (such as mean, frequency and percentage) and inferential statistics (probit regression analysis) were used to analyze the data.

\section{Results and Discussion}

\section{Socioeconomic characteristics of maize farmers}

Survey responses were obtained from 173 respondents across 5 communities out of which, after data cleaning, 158 were analysed consisting of more men $(93.0 \%)$ than women $(7.0 \%)$ as presented in Table 2. This result shows that men are more involved in maize farming. Because of the influence of tradition and religion women are generally 
restricted to purdah in their compounds where they process food for consumption. Most household heads prefer to engage their wives in non-farm activities as reported by Mbavai (2012) in a study of cowpea farmers in Musawa L.G.A. of Katsina States.

Age has been found to determine how active and productive the head of the household would be. As shown in Table 2, majority of the respondents $(78.6 \%)$ were within the active age range of $25-54$ years. 
Table 2: Some socioeconomic characteristics of the respondents

\begin{tabular}{|c|c|c|}
\hline Characteristics & Frequency $(\mathrm{n}=158)$ & Percentage (\%) \\
\hline \multicolumn{3}{|l|}{ Gender } \\
\hline Male & 147 & 93.0 \\
\hline Female & 11 & 7.0 \\
\hline \multicolumn{3}{|c|}{ Age range of respondents } \\
\hline $15-24$ & 2 & 1.3 \\
\hline $25-34$ & 36 & 22.8 \\
\hline $35-44$ & 48 & 30.4 \\
\hline $45-54$ & 40 & 25.3 \\
\hline $55-64$ & 25 & 15.8 \\
\hline 65 years and above & 7 & 4.4 \\
\hline \multicolumn{3}{|l|}{ Marital status } \\
\hline Single & 9 & 5.7 \\
\hline Monogamously married & 93 & 58.5 \\
\hline Polygamously married & 56 & 35.2 \\
\hline Divorced & 1 & 0.6 \\
\hline \multicolumn{3}{|l|}{ Educational level } \\
\hline None & 23 & 14.5 \\
\hline Primary & 35 & 22 \\
\hline Secondary & 16 & 10.1 \\
\hline Tertiary & 9 & 5.7 \\
\hline Qur'anic & 76 & 47.8 \\
\hline \multicolumn{3}{|c|}{ Membership of Association } \\
\hline Yes & 111 & 69.8 \\
\hline No & 48 & 30.2 \\
\hline \multicolumn{3}{|l|}{ Off farm activity } \\
\hline Yes & 94 & 59.7 \\
\hline No & 64 & 40.3 \\
\hline \multicolumn{3}{|l|}{ Extension contact } \\
\hline Yes & 126 & 79.7 \\
\hline No & 32 & 20.3 \\
\hline \multicolumn{3}{|l|}{ Access to credit } \\
\hline Yes & 10 & 6.5 \\
\hline No & 143 & 93.5 \\
\hline \multicolumn{3}{|l|}{ Participation } \\
\hline Yes & 68 & 44.7 \\
\hline No & 84 & 55.3 \\
\hline
\end{tabular}

Access to extension has been widely reported to positively influence adoption and continued use of agricultural technologies. The result showed that $79.7 \%$ of the respondents had contact with extension agent. Most of the contact was made with ADPs $(64.5 \%)$ while $25.8 \%$ was from contact with researchers from the SS Taskforce while $6.5 \%$ was coming from NGO. Farmers must have information about the intrinsic characteristics of an improved variety before they can consider adopting it or not. Contact with extension agents exposes farmers to information on new ideas and technologies during the year and on the importance and application of new innovations through 
counselling and demonstrations by extension agents on a regular basis. It can therefore stimulate adoption. The extent of contact with extension agents among both participants and non participants was quite encouraging. This was probably due to the fact that the Sudan Savannah Taskforce through its researchers and extension agents was always available to train and supervise farmers. Similarly Bamire et al. (2010), reported that 84\% of households in the Sudan Savanna of Southern Borno had access to extension services with the major activities through a project called PROSAB, thereby confirming the positive influence of the project. In the same vein Onu (2006) found that farmers who had access to extension adopted improved farming technologies had $72 \%$ productivity growth rate than those who had no access to extension services.

The result shows that only $6.6 \%$ of the respondents had access to credit. This indicates that most of the farmers did not have access to credit. This may limit the adoption of improved technologies including the improved maize or may not increase area under cultivation. Access to credit is important in influencing the likelihood of adoption of improved maize seed among farmers. The importance of agricultural credit in production cannot be over emphasized. Most farmers fear trying improved technologies because they do not have the necessary financial resources to adopt such technologies.

The results show that $44.7 \%$ of the respondents participated in maize related activities while $55.3 \%$ of the respondents did not take part in the activities promoted by the project. It was noticed during the survey that a large number of the participants of the project ended up adopting the varieties while just a very small percentage of the non participants adopted the variety.

It also indicates that most of the respondents were married with $58 \%$ being in monogamous marriages, $35.2 \%$ in polygamous marriages and only a small proportion $(5.7 \%)$ single. The high number of married respondents may lead to higher adoption of agricultural technologies. This could largely be due to the fact that the married have more responsibilities to shoulder in terms of meeting at least the basic needs of their family members especially feeding. It is expected that family labour would be more available where the farmers are married.

Furthermore, the results show that $22 \%, 10.1 \%$, and $5.7 \%$ of the farmers had primary, secondary and tertiary education respectively while $47.8 \%$ had Qur'anic education which was the highest owing to the fact that the study area is a predominant Muslim community where Islamic knowledge is given a high priority. The low level of formal education may limit adoption of improved technologies including the improved maize varieties.

Results also indicate that $69 \%$ of the respondents belonged to associations. This implies that farmers in this area may tend to adopt improve technologies. According to Yanguba (2004) membership of an association enables farmers to interact with other farmers, share their experiences and assist themselves. Bamire et al. (2010) found that interaction of farmers with other farmers is an avenue through which diffusion of innovation can occur. 
Furthermore, $59.7 \%$ of households were engaged in other activities apart of farming. Off farm activities usually widens the possibility of adopting an innovation by mitigating the shortage of capital input for investment in farming activities. Off-farm income can be used to purchase inputs for farming.

\section{Household size, farming experience and maize growing experience}

As shown in Table 3, the average household size was about 12 persons per household. One of the most important factors conditioning the level of production and productivity of small scale farmers is the composition and size of the family. Hence the relatively large family size of the family is an obvious advantage since it may likely enable the farmers to use family labour, thereby reducing labour cost in maize production. Compared to results obtained in various studies, household size was higher in the study area suggesting that the farmers had a high number of labour-force for farming activities which is indicative of the high adoption rate in the area.

Mean farming experience of households was 25.08 years. This indicates that most of the farmers have been practicing farming for long. The accumulated years of experience may help farmers in crop selection and enable them to evolve the farming practices that are most suitable to their fragile environment. This is in line with the findings of Bamire et al. (2010) who reported that long years of farming enhance the likely adoption of new technologies. Agwu (2004) also reported average years of farming experience in Gombe State in northern Nigeria to be 22.6 years indicating that farmers in the region have several years of experience in farming and therefore will be conversant with the constraints to increased cowpea production.

Table 3: Some more socioeconomic characteristics of the respondents.

\begin{tabular}{lrrr}
\hline & Household size & Farming experience & Years growing maize \\
\hline Mean & 12 & 25.08 & 11.40 \\
Std Deviation & 12.842 & 10.808 & 8.886 \\
Minimum & 1 & 1 & 1 \\
Maximum & 21 & 50 & 40 \\
\hline
\end{tabular}

\section{Factors Determining the Adoption of Improved Maize Varieties}

Eleven variables were hypothesized to influence the probability of farmers' adoption of improved maize varieties in the study area as shown on Table 4. Out of these, four (4) were found to be significant. These variables include farmers' marital status, farmers' participation in extension activities, educational level of farmer and household size.

Household size was found to be significant at $5 \%$ and negatively related to adoption of improved maize varieties. This means that family size is inversely related to adoption of improved maize varieties in the study area. The likelihood of adoption will be more in smaller households than in larger households. This is in agreement with Amegbeto et al. (2001) who reported that large family size reduce the chance of adoption of improved cassava varieties in east central Nigeria. Similarly, Polson and Spencer (2004) noted that because subsistence households are resource poor, large family size may, in reality not contribute significantly in increasing the resource pool of the family, especially if some 
family members (school age children) are not full time farm operators. Since the household head is in charge of production decisions, other family members have very limited input in adoption decisions.

Participation in promotional activities by the project was significant at $1 \%$ and positively related to adoption of improved maize varieties. This suggests that most of the people who participated in the project activities had likelihood of adoption of the introduced varieties more than those who did not. These activities informed and built the capacity of farmers, increasing their knowledge and reducing their uncertainty in decision making. This result is in agreement with the findings of Alene and Manyong (2007) who reported that regular contact with extension raises improved cowpea production by an average of $18.5 \%$ but the contact has no significant effect on cowpea production under traditional technology.

Marital status of the farmer was found to be significant at $5 \%$. This is indicative that adoption is likely to occur when farmer is married than when he is not. This could largely be due to the fact that the married have more responsibilities to shoulder in terms of providing basic need of their family with food being the most important. Thus, any technology that will increase the production of food or provide likelihood of food security for his/her family will be adopted. The improved maize varieties are high yielding thus would increase food supply.

Table 4: Factors influencing the adoption of early maturing maize varieties.

\begin{tabular}{|c|c|c|c|c|c|c|}
\hline Variables & Coef & S.E & Wald & Df & Sig & $\operatorname{Exp}(B)$ \\
\hline Sex of household head & -1.310 & 1.131 & 1.341 & 1 & 0.247 & 0.270 \\
\hline Age of household head & -0.203 & 0.269 & 0.573 & 1 & 0.449 & 0.816 \\
\hline Marital status of household head & 1.163 & 0.561 & 4.302 & 1 & $0.038^{* *}$ & 3.200 \\
\hline Household size & -0.112 & 0.056 & 3.940 & 1 & $0.047^{\star \star}$ & 0.894 \\
\hline $\begin{array}{l}\text { Educational level of household } \\
\text { head }\end{array}$ & 0.449 & 0.241 & 3.475 & 1 & $0.062^{\star * \star}$ & 1.567 \\
\hline Membership of association & 0.019 & 0.375 & 0.003 & 1 & 0.959 & 1.019 \\
\hline Land ownership & -0.149 & 0.370 & 0.162 & 1 & 0.687 & 0.862 \\
\hline Extension contact & -0.177 & 0.504 & 0.123 & 1 & 0.726 & 0.838 \\
\hline Participation in activities & 4.144 & 1.241 & 11.155 & 1 & $0.001^{*}$ & 63.059 \\
\hline Access to agrochemical dealer & 0.118 & 0.788 & 0.022 & 1 & 0.881 & 1.125 \\
\hline Access to seed dealer & 18.234 & $6.986 \mathrm{E} 3$ & 0.000 & 1 & 0.998 & $8.296 \mathrm{E} 7$ \\
\hline Constant & -46.361 & 1.397E4 & 0.000 & 1 & 0.997 & 0.000 \\
\hline
\end{tabular}

Educational level of the farmers was found to be significant at $10 \%$ and positively related to adoption of improved maize varieties. This means that the higher the person has formal education, then the higher there is the likelihood of adoption. This is in line with results of study by Ebojei et al. (2012) in northern Nigeria who reported that farmers who were educated are four times more likely to take part actively in hybrid maize technologies than those who were illiterates. This outcome was likely because those who can read and write are at a lead in perception and deduction of recommended packages. Therefore, the 
likelihood of participation in hybrid maize production increases with increase in years of schooling, as risk aversion decreases. Similarly, Alene and Manyong (2007) stated that education increases the ability to assess, interpret, and process information about a new technology, and therefore has a positive impact on the decision to adopt and use a technology. Amaza et al. (2009) also cited that education increases agricultural productivity and improves the livelihood of farmers.

\section{Constraints to Adoption of Improved Maize Varieties}

Although the production of improved maize varieties in the area was promising, the respondents reported problems they faced during cultivation. Table 5 shows the major constraints faced by farmers growing these varieties. The result showed that inadequacy of seed was the major constraint $(75.6 \%)$; followed by inadequacy of fertilizer with $69.0 \%$. Cost of seed being the third constraint faced by farmers in the study $(57.8 \%)$. Thus the unavailability of seed and fertilizer were major constraints to adoption as all of the varieties promoted needed fertilizer for maximum output to be realised. Similarly, Gyasi et al. (2003) discovered that lack of improved seeds and fertilizer were the major constraints to the adoption of improved maize varieties in northern Ghana. Also Sanginga (1998) cited fertilizer and lack of labour being the major constraint inhibiting the adoption of soybean Benue State.

Table 5: Major adoption constraints faced by farmers in the area

\begin{tabular}{llll}
\hline Constraints & Frequency & Percentage(\%) & Rank \\
Unavailability of seed & 34 & 75.6 & $1^{\text {st }}$ \\
Inadequacy of fertilizer & 29 & 69.0 & $2^{\text {nd }}$ \\
High cost seed & 26 & 57.8 & $3^{\text {rd }}$ \\
\hline
\end{tabular}

\section{Conclusion}

Out of the eleven variables were hypothesized to influence the probability of farmers' adoption of improved maize varieties were found to be significant. Household size and marital status of the farmers were found to be significant at $5 \%$ each; however, the former was negative while the later was positively related to adoption. Adoption of improved maize varieties was positively influenced by both participation in promotional activities and educational level of household head at $1 \%$ and $10 \%$ levels of significance respectively. Therefore, in order to increase the adoption and widespread use of the improved varieties policy efforts should be made to link farmers with certified seed companies and also provide farmers with subsidized fertilizer. This would go a long way to improve on productivity, increase food security in the homes, reduce poverty level in the communities and generally enhance the livelihood of the small-scale farming households. It is also recommended that participatory approach should be encouraged in disseminating improved agricultural technologies like this because, participation is the most significant factor influencing adoption of improved maize technologies in the study area. 


\section{References}

Agwu, A.E. (2004). Socio-economic characteristics and technology-related factorsinfluencing adoption of improved cowpea production technologies among farmers in Bauchi and Gombe States, of Nigeria: Journal of International Agricultural and Extension Education, 11(1):81-88.

Alene, A. D. and Manyong, V. M. (2007). Gains from High-Yielding Varieties with and without Complementary Technologies: The case of Improved Cowpea in Northern Nigeria. Journal of Agricultural and Food Economics, 2(1): 1-14.

Amaza, P., Abdoulaye, T., Kwaghe, P. and Tegbaru, A. (2009). Changes in households' food security and poverty status in PROSAB areas of Southern Borno State, Nigeria. International Institute for Tropical Agriculture (IITA) Promoting Sustainable Agriculture in Borno State (PROSAB), April, 2009.

Amegbeto, K.N., V.M.Manyong, R.Asiedu and O.Coulibaly .(2001). Technology adoption within yam-based systems: prospects for the diffusion of improved yam varieties in Nigeria. IITA annual report, 2001 Impact policy and system. 90-94.

Ayanwale A., Abdoulaye T., Ayedun B., and Akinola A., (2011). Baseline Report of theSudan Savannah Zone Of The Kano-Katsina-Maradi Pilot Learning Sites of The Sub Saharan Africa-Challenge Program (SSA CP).

Bamire S. A., Abdoulaye T., Amaza P., Tegbaru A. Alene A.D.,and Kamara A.Y. (2010):Impact of promoting sustainable Agriculture in Borno (PROSAB)Program adoption of improved crop varieties in Borno State of Nigeria. Jounal of food, agriculture and Environment. 8 (3\&4): 391-398.

Dugje, I. Y., Omoigui, L. O., Ekeleme, F., Kamara, A. Y., \& Ajeigbe, H., (2009). Farmers Guide to cowpea production in West Africa. IITA Ibadan, Nigeria.

Ebojei, C.O., Ayinde, T.B. and Akogwu G.O. (2012). Socio-economic factors influencing the adoption of hybrid maize in Giwa LGA Kaduna State, Nigeria. The Journal of Agricultural Science: 7(1)

Gyasi, K.O., L.N. Abatania, T. Paulinus, M.S. Abdullahi. And A.S. Langyintuo (2003). A study of the adoption of improved maize technologies in northern Ghana. 365378.

Kamara, A.Y., A. Menkir, B. Badu-Apraku, and O. Ibikunle. (2003).Reproductive and staygreen trait responses of maize hybrids, improved open-pollinated cultivars and farmers' local cultivars to terminal drought stress. Maydica 48:29-37.

Mbavai J.J. (2012) an assessment of the effectiveness of the Sudan Savannah Taskforce project in the adoption and diffusion of improved cowpea varieties in selected communities in Musawa LGA of Katsina State. Unpublished MEd thesis submitted to Bayero University, Kano. 
Onu D. O. (2006). Socioeconomic factors influencing farmers' adoption of alley farming technology under intensified agriculture in Imo state, Nigeria. The Philippine Agricultural Sceintist 89(2):45-52

Polson, R.A. and D.S.C. Spencer (2004). The technology adoption process in subsistence agriculture: The case of cassava in South-western Nigeria. Farming systems. 36:65-78.

Sanginga, P.C. (1998). Adoption and social impact assessment of improved agricultural technologies: the case of soybean in Benue State Nigeria. Unpublished Ph.D. thesis, university of Ibadan.

Yanguba A. (2004). Agricultural technology adoption by small-scale farmers: The case of extra-early maize varieties in the Sudan savannas of Katsina State, Northern Nigeria. Unpublished M.Sc. Thesis: University of Ibadan, Nigeria. 